Canadian Journal of Higher Education

Revue canadienne d'enseignement supérieur

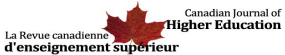

\title{
Book review of "International Service Learning: Engaging Host Communities"
}

\section{Melanie Rathburn}

Volume 47, Number 3, 2017

URI: https://id.erudit.org/iderudit/1043246ar

DOI: https://doi.org/10.7202/1043246ar

See table of contents

Publisher(s)

Canadian Society for the Study of Higher Education

ISSN

2293-6602 (digital)

Explore this journal

Cite this review

Rathburn, M. (2017). Review of [Book review of "International Service

Learning: Engaging Host Communities"]. Canadian Journal of Higher Education

/ Revue canadienne d'enseignement supérieur, 47(3), 197-199.

https://doi.org/10.7202/1043246ar

Copyright (c) Melanie Rathburn, 2017

Attribution-NonCommercial-No Derivative Works 2.5 Canada
This document is protected by copyright law. Use of the services of Érudit (including reproduction) is subject to its terms and conditions, which can be viewed online.

https://apropos.erudit.org/en/users/policy-on-use/ 
Canadian Journal of Higher Education Revue canadienne d'enseignement supérieur

Volume 47, No. 3, 2017, pages 197 - 199

\section{Book Review / Compte rendu}

\section{Larsen, Marianne A. (Ed.) (2015). International Service Learning: Engag- ing Host Communities. New York: Routledge. Pages: 288. Price: 45.95/163.00 USD (paper/hardcover).}

Reviewed by Melanie K. Rathburn, Associate Professor, Mount Royal University, Calgary, Alberta.

In this edited collection, Marianne Larsen has brought together academics, non-profit organizations, and community partners to reflect on their experience working with International Service Learning (ISL) programs. The approach of this book is to critically examine the effects of ISL programs on host communities, highlighting the lack of community voice and acknowledgement in ISL experiences. Much of the book is framed in critical theories and the authors clearly articulate that the goal of this collection is to "problematize not only ISL research and practices but also the value, knowledges, and assumptions that underlie ISL" (p. 10). This is not the standard reflection that promotes the effectiveness of ISL with a few recommendations, but rather a critical analysis of ISL by considering questions of ethical engagement, potential harm, and challenges for host communities. From these critiques emerge thoughtful and considered ways of shifting our thinking of ISL programming to benefit not only our students but the many communities in which we work.

This book is divided into three sections. The first section provides an overview and grounds the discussion in a theoretical framework. In the first chapter, Larsen provides a lens for the upcoming chapters by highlighting the existing literature as well as our assumptions about host communities. Although there have been increasing calls in the literature to engage with host communities, Larsen's review underscores the lack of research and information about the effects on communities. The second chapter is a conversation among the authors that focuses on the epistemological, methodological and theoretical challenges of conducting research on ISL programs. This chapter is written in a dialogical format where the reader is, in essence, eavesdropping on the conversation of others. Although unsettling at first, I found that the style engages the reader and makes you want to talk back to the authors. I commend the authors for sharing this honest and vulnerable discussion. 
The second section of the book transitions into various case studies, mainly based out of Canadian universities. These cases document the community perspective by hearing from host families, community participants, and coordinators/facilitators from various countries. The importance of hearing these multiple perspectives cannot be overstated; each of the eight case studies provides a nuanced and rich understanding of the impacts of ISL as expressed by the community. Reynolds and Gasparini (Ch. 3) investigated the motivations of community participants and found that they see themselves as co-educators in the students' learning. In their analysis, O'Sullivan and Smaller (Ch. 4) found that community members were overwhelmingly positive in their overall reflections on the ISL program; however, the authors noted tensions between ISL programs and the community that centered around miscommunications and misperceptions on the part of both parties. Toms Smedley (Ch. 5) found that the communities' main benefit was economic; assistance with community development projects was secondary. Although these economic benefits are helpful to community participants, the researchers were left questioning the value of ISL projects and whether communities are receiving meaningful contributions from their participation.

Issues of power are inherent in all service-learning projects, especially those between the global North and South. The concepts of power and privilege arose as important issues in chapters 6 and 7. Heron (Ch. 6) found that as practitioners we approach communities with a certain discourse and interpretation that might be different from those of community members. These alternative views can shape how both students and the community interpret each other and their actions. Similarly, in chapter 7, Larsen noted that concepts of power and privilege surfaced in her interviews with community participants and informed their interactions with ISL participants. These findings illustrate the importance of recognizing issues of power so that we can shift the balance to the community in order to build reciprocity in our interactions.

Reciprocity emerged through the book but was a central to the discussion in chapters 8,9 , and 10 . Arends' interviews with community partners showed that many partnerships are not considered reciprocal and some individuals considered the relationship with ISL programs to even be exploitative (Ch. 8). These findings highlight the importance of clarity about the project and individuals' roles in the project to avoid "uncertainty, cultural misunderstanding, misinterpretation, and mistreatment" (p. 113) so that we can create relationships that are truly reciprocal in nature. In chapter 9, Jorgenson focuses on the importance of pre-departure education for students that includes critical reflection and analysis of ethical intensions, to avoid some of these same conflicts. The research presented in Chapter 10 by MacDonald and Vorsterman stresses the importance of engaging community members, beyond the token nature of so many ISL programs. Host communities are calling for engagement in ISL programming and it is essential that we consider their expectations and motivations as central to this endeavor. The authors also emphasize the need for practitioners to work with students to also see the hosts as participants in their learning. It is one thing to engage communities with programming, but for a reciprocal, meaningful relationship to develop, students need to understand and respect the role of the community in their learning.

The final section of this book entitled "Rethinking and Re-imagining ISL and Host Community Relations" (p. 145) contains eight chapters that discuss how we can move for- 
ward with better acknowledgement of the effects of ISL on communities. These chapters give a voice to local coordinators and community participants and provide concrete recommendations so that we can construct more meaningful and authentic relationships. The authors of these chapters focus on recommendations to ensure that ISL programs are focused on actual community needs with an embedded cultural understanding (Ch. 11), the development of reciprocal relationships (Chs. 12-14, and 17), and ethical consideration of engaging in ISL activities (Chs. 15-16, 18). In fact, some of the chapters also include detailed frameworks (Table 16, p. 226) and standards (Ch. 17, Appendices) to assist others in developing and assessing the success of these principles in their own ISL programs. In the final chapter of this edited book, Kozak and Larsen review the relationships and responsibility for practitioners engaged in ISL activities with a discussion of the benefits and potential harms of this practice and outline key recommendations. These authors argue for a paradigm shift among academics from a focus on students to a focus on the communities.

Overall, this book provides a powerful and critical interrogation of ISL practice. For years, the focus has been on the student experience with little regard for the communities that support our activities. ISL programs have the potential to do great harm by reinforcing power dynamics, contributing to global inequality, and promoting neocolonialism. As Agudey and Deloughery state in chapter 14, “...if ISL is not going to be done well, it should not be done at all, because the consequences are significant and real” (p. 199). Anyone involved in ISL programs should read this book and thoughtfully consider each of the recommendations. This book has the potential to revolutionize our practices, which will in turn better support both students and our global communities. 